\title{
Envisioning the Archipelago
}

Elaine Stratford

School of Geography and Environmental Studies

University of Tasmania

Hobart, Tasmania, Australia

Elaine.Stratford@utas.edu.au

Godfrey Baldacchino

Island Studies Program

University of Prince Edward Island, Canada

gbaldacchino@upei.ca

Elizabeth McMahon

School of English, Media \& Performing Arts

University of New South Wales

Sydney, Australia

e.mcmahon@unsw.edu.au

Carol Farbotko

School of Earth and Environmental Sciences

University of Wollongong

carol.farbotko@gmail.com

and

Andrew Harwood

School of Geography and Environmental Studies

University of Tasmania

Hobart, Tasmania, Australia

aharwood@utas.edu.au

Abstract: Certain limitations arise from the persistent consideration of two common relations of islands in the humanities and social sciences: land and sea, and island and continent/mainland. What remains largely absent or silent are ways of being, knowing and doing — ontologies, epistemologies and methods - that illuminate island spaces as inter-related, mutually constituted and co-constructed: as island and island. Therefore, this paper seeks to map out and justify a research agenda proposing a robust and comprehensive exploration of this third and comparatively neglected nexus of relations. In advancing these aims, the paper's goal is to (re)inscribe the theoretical, metaphorical, real and empirical power and potential of the archipelago: of seas studded with islands; island chains; relations that may embrace equivalence, mutual relation and difference in signification.

Keywords: archipelago; assemblages; constellations; island relations; island studies; method; repetition

(C) 2011 Institute of Island Studies, University of Prince Edward Island, Canada. 


\section{Openings}

Contemporary scholarship in the social sciences and the humanities tends to settle upon two somewhat overworked topological relations of islands. The first predominant relation presents a clear focus on islands' singularity, unique histories and cultures, crafted and inscribed by the border between land and sea. The second distinguishes islands from mainlands/continents, and dwells on their differences from these larger settings.

Both relations serve various purposes: the first, perhaps, for espousing the specificity and identity claims of island peoples for their own spaces, voices and practices, and reversing the exotic renditions of island tropes and lives; the second, for celebrating or critiquing neocolonial and postcolonial subordinations, and marking attendant tensions in islandmainland affairs - for example, in geopolitics. Nevertheless, the tendency in island studies scholarship to focus on such relations, often categorically, cannot do justice to the rich subject matter at hand. Indeed, such rhetorics can be conscious and unconscious acts to reduce and manage complexity for convenience, benign indifference, or malevolent resolve; they produce dominant discourses about and on islands and islanders rather than with, from or for them. With Edmond \& Smith (2003: 7), we advocate a scholarship that deploys the island as "a model, rather than simply a site" of investigation. Hence, the question: what model/s and how can island studies scholars attend to the range, specificity and dynamism of their inter-relation?

Thus, these prevailing topological relations do not engage with less defensive, potentially novel, powerful and revealing commonalities and relations of islands qua islands. There is need, then, to articulate new research agendas to explore alternative cultural geographies and alternative performances, representations and experiences of islands. Different relations need to be thought through, and established relations considered differently. In short, we seek to understand archipelagos: to ask how those who inhabit them or contemplate their spatialities and topological forms might view, represent, talk and write about, or otherwise experience disjuncture, connection and entanglement between and among islands. In doing so, we first assume, a priori, and then seek to map, the existence, implications and affect of archipelagic relations. The latter arise "in the midst of in-between-ness: in the capacities to act and be acted upon [by] ... forces or intensities ... that pass body to body (human, nonhuman, part-body, and otherwise)" (Seigworth \& Gregg, 2010: 1).

Acknowledging these foundational assumptions, presumptions about how archipelagic relations manifest, operate or circulate are to be avoided nevertheless. Rather, their possibility may provide novel opportunities to unsettle certain tropes: singularity, isolation, dependency and peripherality; perhaps even islandness and insularity. Tracing the existence, implications and affect of archipelagic relations will also demand and expect various theoretical, methodological and empirical innovations if island scholars and colleagues in allied fields are to understand how this 'world of islands' (Baldacchino, 2007) might be experienced in terms of networks, assemblages, filaments, connective tissue, mobilities and multiplicities. This tracing of archipelagic relations may constitute a form of counter-mapping, which DeLoughrey (2007) has termed archipelagraphy: a re-presentation of identity, interaction, space and place that comes across in different combinations of affect, materiality, performance, things. Such counter-mapping requires a double-destabilization: dislocating and de-territorializing the objects of study - the fixity of island difference and particularity - and constituting in their place a site or viewing platform by which they are perceived and analysed afresh and anew. 


\section{Island Relations}

Islands embody a "contradictory geography" (Williams, 2010: 290). Their spatialities are characterized typically by three relatively durable topological and binary relations: land and water, island and continent/mainland, and island and island; in Olsson's (1992) terms, these relations invoke ideas of difference, mutual relation and equivalence. Island-to-island relations are under-theorized and attended by limited fieldwork or other forms of empirical research. These relations can be thought about as generalized abstract conditions within which the particular spatiality of any island is constituted and from which derive various amplifying, intersectional and cross-cutting dynamics. Drawing upon various works, including Harwood's (2011) synthesis of island studies and the topology of philosopher Michel Serres, the key features of these three topological relations are considered below.

First, for many island studies scholars who have sought definition of their subject matter, islands are principally distinguished by an intense and enduring relationship between land and water. In western modernity at least, that an island is classically thought about as "a piece of land surrounded by water" "identifies at least three critical aspects of islandness. The elemental qualities of land and water are brought to the foreground, positioning islands as quintessentially 'natural' places where "material values lose their despotic influence: one comes more directly in touch with the elemental-water, land, fire, vegetation, wildlife" (King, 1993: 14). In similar vein, Beer (1989: 5) has noted that the

... idea of the island allows us at once the satisfactions of water and of earth, of deep flux and steadfast fruitfulness. At the same time it expresses the dreads of water and of earth, twin desolations, in which the self drifts or is confined, in which loneliness or loss predominate.

The boundary marked by land and water identifies a fundamental disjuncture in spatiality; the island split between two basic forces. In an essay entitled 'Desert Islands' Deleuze (2004: 9) discusses these two elements and their ongoing struggle and notes that "People like to call these two elements mother and father". DeLoughrey $(2007: 5,12,25)$ also attends carefully to the gendered binary of land (masculine) and water (feminine) and considers how the gender meta-binary shapes and propels this contest of spatialities. Hence, while islands signify a "specific becoming or mutual achievement of land and water" (Harwood, 2011: 41), the spatiality of the island also sets up a basic opposition or "eternal contest" (King, 1993: 14) between these elements, often resolved in favour of land at the expense of water. The boundary marked by land and water is a critical feature of islands but by no means is it definitive, for the land and sea boundary is a shifting, fractal and paradoxical one, present in many spatialities (Dening, 2004). What does define is the complete encircling of land by water. The creation of distinctive 'inside' and 'outside' spaces implied in the boundedness of islands highlights two ideas of them: as complete in and of themselves; and as isolated from others and insular unto themselves (Baldacchino, 2008; DeLoughrey, 2007; Farbotko, 2008; Harwood, 2011; Hau'ofa, 1993; McMahon, 2010; Stratford, 2008).

\footnotetext{
1 The 1861 UK census decreed that an island is "any piece of solid land surrounded by water which affords sufficient vegetation to support one or two sheep, or is inhabited by man" (Berry, 2009: 10). Gillis (2004: 84) dates possibly the first use of 'island' to mean a land surrounded by water: 1555 by Portuguese historian Antonio Galvano.
} 
The second topological relation of the island discernible within island studies is that it is typically held in opposition to a continent, a relation which is usually materialized as a particular mainland. In a sense, islands and continents are each other's 'other' (GibsonGraham, 1998; Said, 1978). On the surface, this relationship is characterized by a difference in size: islands are small, continents are very large. However, attempting to distinguish islands from continents/mainlands in terms of absolute size of land area or population, for example, works against a relational understanding. Indeed it seems most islands invariably embrace other islands within their spatial ambits: smaller islands off their coasts; larger islands (mainlands?) to which they belong; and internal islands (of interest, conflict or other assemblages, for instance) that may exist should their boundedness be fractured (Baldacchino, 2002; Stratford, 2006). Rather, the scalar relationship between island and continent points towards relative differences and representations whereby islands are seen as necessarily smaller than continents. Indeed, islands - and their constituent residents and dynamics - are routinely perceived and expected to be vulnerable, fragile, dependent and problematic on the basis of a categorical difference that is assumed to exist between continents/mainlands and islands, and which privileges the larger land mass ${ }^{2}$. The binary between continent and island is "structured by hierarchies of value, as much as size: presence/absence, sufficiency/insufficiency, positivity/negativity, completeness/lack" (Gibson-Graham, 1998: 2). Such a mix of categorical and relative evaluations positions islands as both microcosms of continents/mainlands as well as quintessentially different or particularized others.

A third topological relation is much less commonly deployed than the previous two; it foregrounds interactions between and among islands themselves. A complex and manifold lineage of real and imaginary places may be mobilized in any given instantiation of 'island'. Yet, for various reasons - historical, geographical, political and economic-multiplicities of islands have gravitated towards some putative 'unity'. Alternatively, an archipelagic feature of islands is exemplified in Benítez-Rojo's (1996: 1) idea of "the repeating island":

In recent decades we have begun to see a clearer outline to the profile of a group of American nations whose colonial experiences and languages have been different, but which share certain undeniable features. I mean the countries usually called "Caribbean" or "of the Caribbean basin". This designation might serve a foreign purpose - the great powers' need to recodify the world's territory better to know, to dominate it - as well as a local one, self-referential, directed toward fixing the furtive image of collective Being (emphasis added).

Moreover, this Being is:

... a discontinuous conjunction (of what?): unstable condensations, turbulences, whirlpools, clumps of bubbles, frayed seaweed, sunken galleons, crashing breakers, flying fish, seagull squawks, downpours, nighttime phosphorescences, eddies and pools, uncertain voyages of signification; in short, a field of observation quite in tune with the objectives of Chaos ... Chaos looks toward everything that repeats, reproduces, grows, decays, unfolds, flows, spins, vibrates, seethes ... Chaos provides a space in which the pure sciences connect with the social

\footnotetext{
${ }^{2}$ There are a few exceptions, such as Singapore-Malaysia, which justify the rule (Barter, 2007).
} 
sciences, and both of them connect with art and the cultural tradition (BenitezRojo, 1996: 2-3; parentheses in original).

For Benítez-Rojo, analysis of repeating, decaying, unfolding, changing islands proceeds "under the influence of this attitude" (ibid.: 3). Such a "clear outline" (ibid.: 1) remains largely under-utilized to date, and is worth further and more penetrating attention. At first glance, it is a liberating rubric of repetition that avoids categorization, one effect of which simplifies and stereotypes in order to numb and subjugate (Said, 1978). Yet there is something about the privileging of 'repetition' that is troubling: repetition can mean duplication, or cloning; and yet no two islands are ever alike.

Thus 'repeated islands' and archipelagos are not the same thing. Indeed, for the notion of repetition to hold, it has to be specified in terms of a particular and paradoxical understanding: Benítez-Rojo (1996: 3) uses the term in the "discourse of Chaos" where every repetition is a practice that necessarily entails a difference and a "step towards nothingness"; this chaos is liberating because the reader so attuned has access to the "opening of unexpected corridors allowing passage from one point to another in the labyrinth". Here, then, we are concerned with the model itself, and concur with DeLoughrey (2007) that it also describes modes of colonial expansion, and specifically that pertaining to England, which came to be constituted as the island of Great Britain, then repeated itself across the Caribbean. Glissant (1997: 14) too, writes of this colonial transposition that the capitals of conquerors "went where they went. "Rome is no longer in Rome, it is wherever I am"'. Repetition is not the answer in itself: somehow it does not escape the overarching structures and dynamics of power. Hence, the possibilities in Benítez-Rojo's work need to be taken up with careful consideration.

Pocock (2005: 29) offers a different explanatory rubric while invoking the concept of "the Atlantic archipelago". This term replaces that of the British Isles, and reflects a sub-continental amalgam off the coasts of northwest Europe wherein resides a historically uneasy and problematic relationship between and among England, Scotland, Ireland and Wales. This history is not a continental or Euro-centric narrative of Britain and of the origins of its empire. Rather, it is one that sees "people in motion, histories traversing distance ... [and in oceans] "not in narrow seas ... and 'identities' (the term is overworked) never quite at home" (ibid.: 23, parenthesis in original). Pocock explains how he owes this ontology to another "antipodean archipelago", that of his own New Zealand. He admits that, although living in the continental United States, he still regards the world as "an archipelago of histories rather than a tectonic of continents" (ibid.: 19). He sees histories as "both transplanted by voyagings and generated by settlements and contacts", thus climbing to anticipate some of the post-modern stress on fictiveness and momentariness (ibid.). In turn, Bourke's (2010: 767) reading of Pocock is noteworthy here, since he emphasizes the latter's "civic understanding of political society" in discussions about identity, plurality and diversity: a point that underscores the importance of context, and one with which we have considerable sympathy.

\section{A Least Examined Metageography}

The relation of island to island is characterized by repetition and assorted multiplicity, acting to intensify, amplify and disrupt relations of land and water, island and continent/mainland (Harwood, 2011). The most common definition of the archipelago is 'a group of islands'. This construct is simple, yet powerful: archipelagic formations are common - the world is one such. 
For example, in different ways the nine circles of suffering in Dante's Inferno or the sixepisode Star Wars series may be read as stories of archipelagic relations. So, too, is Homer's Odyssey, an epic narrative which, as Conrad (2009: 39) notes, "belongs to the different genre of romance, whose storytelling is digressive, elastic, potential endless". More recently and of significance, Caribbean poets such as Walcott $(1991 ; 1992)$, Brathwaite $(1983 ; 1988)$ and Glissant (1997; 2005) have made explicit links between poetics and the relationality of the archipelago. In the visual arts, too, the archipelago underpins a range of representations. Consider sculptor Leo Saul Berk's Archipelago, 2005, a delicate work that conveys the relationality of assemblages of islands, or batik artist Mary Edna Fraser's series on the expanding oceans and on barrier islands, among them Maine Coastline, 1994 or Venice (Italy), 2000 or Magdalene Island (Quebec, Canada) artist Jean-Yves Vigneau's 'atlas of island shapes' (see Figures 1,2 and 3).

In the field of island studies, the archipelago remains one of the least examined metageographical concepts (Lewis \& Wigen, 1997). To us, it now seems strangely absent from, or merely implied in, much island studies scholarship. Indeed, driven as it is by the first two topological relations described in this paper, islands are too often conceived glibly in such scholarship as separate from the very archipelagos they may occupy or constitute (as if the arehipelag did not exist or had been rendered ghostly) ${ }^{3}$. Equally, archipelagos may be erased in descriptions of island groups that reduce them to a single entity, which is in stark contrast to Benítez-Rojo's idea of a collective being or of Pocock's assemblage. A scan by us of weekly Google Scholar alerts for the term 'archipelago' over recent years has mainly landed academic contributions that deploy the archipelago term uncritically as a descriptive, physical geographical referent (for example, the Azores archipelago; the archipelago of Cape Verde). Perhaps there is need to pursue in studies of the archipelago what Fletcher (2011: 18) has proposed for the island: "the idea of 'performative geographies' as an approach to studying the island as a space of cultural production which privileges neither geography or literature (in their narrow senses) but insists on their interconnection".

In our work, the basis for this 'performative geography' (after Fletcher, 2011) —or producing the reality we purport to describe - resides partly in our understanding that the archipelago has been at the core of the constitution of civilizations, collective identities and sovereign states, and central to much scientific discourse. In his analysis of the 'dance of the islands' of the fifth century Ægean, for example, Constantakopoulou (2007) identifies the connectivity between islands as one of the two defining aspects of Ægean 'insularity' - the other being isolation. He writes how, in the Ottoman period, the Ægean Sea was called Adalar Denizi: Sea of Islands. Constantakopoulou emphasizes integration and collaboration when he observes that "islands were understood as distinct 'closed' worlds, ideal locations for the extraordinary and the bizarre, but at the same time they were also perceived as parts of a complex reality of interaction" (2007: 2, emphasis added).

\footnotetext{
${ }^{3}$ In this respect, Maddern \& Adey (2008: 291) remind us that "there are a set of social theories that are now becoming increasingly important to understanding a whole host of spatial and social relationships: a concern with the most spectral aspects of space" that draw on Derridean notions of trace, erasure and the absent presence.
} 
Figure 1: Leo Saul Berk, Archipelago, 2005. Masonite and MDF, 90in x 120in x 3in Sarah and Richard Barton Collection.

www.leosaulberk.com/page/catalog/heading/2815/artwork/6472. Reproduced with permission.

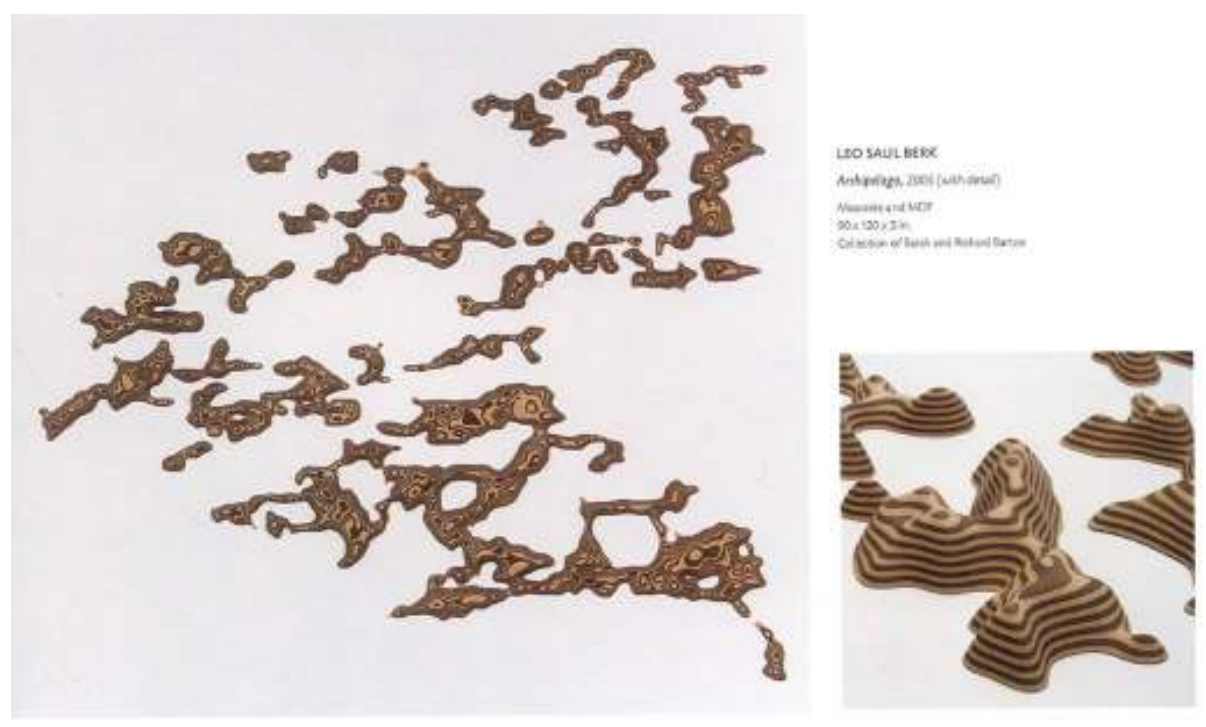

Figure 2: Mary Edna Fraser, Venice (Italy), 2000. 61in x 44in http://maryedna.com/. Reproduced with permission.

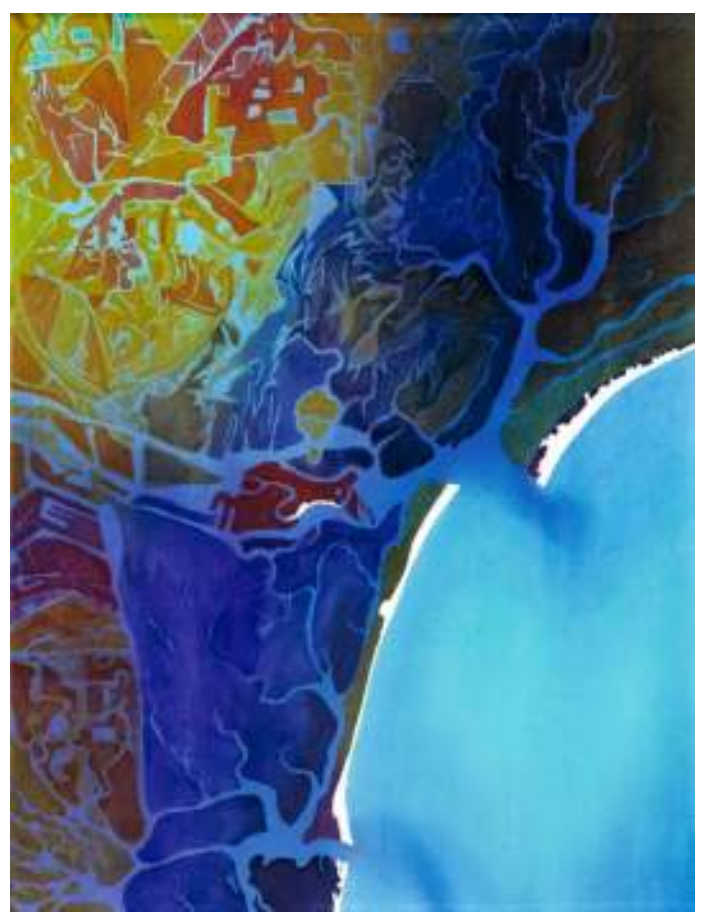


Figure 3: Jean-Yves Vigneau, Atlas of Island Shapes. www.vigjy.net/artiste/proposinsulaires4.htm. Reproduced with permission.

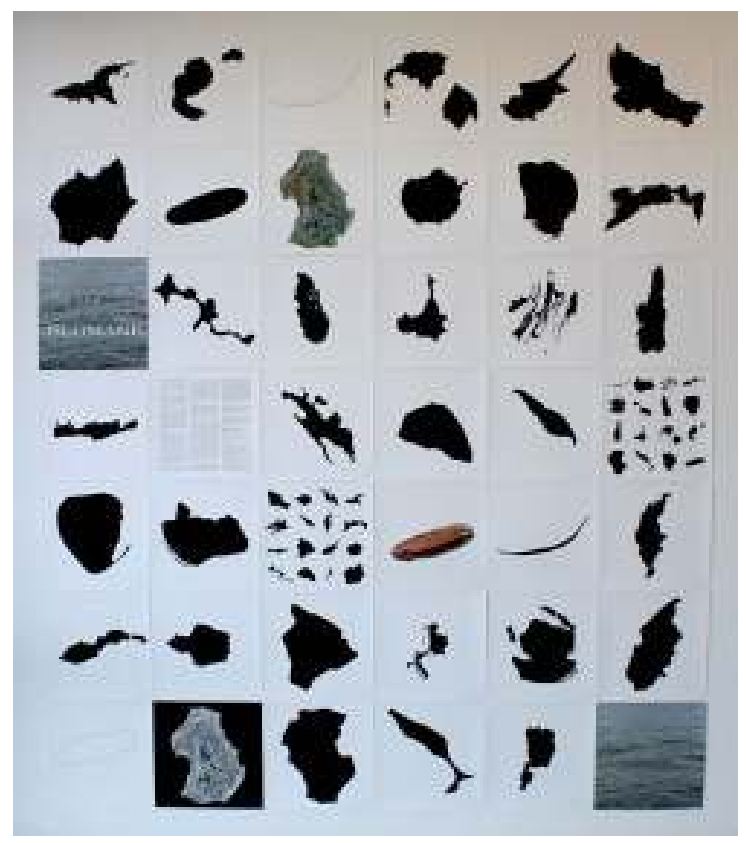

This last point is worth elaboration. The etymology of archipelago provided in the Oxford English Dictionary indicates that the word was "evidently a true Italian compound" of arch (from the Greek signifying 'original', 'principal') and pelago (deep, abyss, sea). The coinage was probably suggested by the medieval Latin name of the Ægean Sea, Egeopelagus. The earliest usage of the word given by the OED occurs in a Treaty of 30 June 1268, between the Venetians and Byzantine Emperor Michael Palaeologus. What may be the first use, then, occurs in the context of the Byzantine empire's reclaimed power in the Ægean. Later uses in the early modern period indicate that the word continued to be used in its specific reference to the Ægean but was also gaining currency as a more general term for a group of islands in the sea. One representative example of this more general usage is found in Richard Hakluyt's influential Divers voyages touching the discouerie of America (1582), in which he writes: "These broken lands and Islands being very many in number, do seeme to make there an Archipelagus" (OED). Here, then, is a usage directly connected to a document promoting the British settlement of America. One further point of interest concerning the term's use occurs in a descriptive passage from Charles Merivale's History of the Romans under the Empire (1865) which states: "that the continent was an archipelago of insulated communities". In Merivale's work, then, the word refers to a collective of insulated-rather than insular-communities. They are not separated by water but by cultural difference and history.

Accordingly, this word, archipelago, rich in ancient resonance, also carries the weight of those histories and discourses. Indeed, it is inevitable that it does so. It is not innocent. Nor does its proposed use here replace or displace the utopian impulse so long associated with the island paradise. The archipelagic relation has, of course, been used cynically and opportunistically in the processes of colonial acquisition: island constellations have been convenient stepping stones of dominion; those shadows should not be forgotten in further analysis of the relationality that archipelagic thinking engenders. As the coinage and early uses of archipelago 
clearly demonstrate, no word exists outside its culture and its utterance. But this relativity does not negate the utility of the term for current purposes. In our own time, the archipelago has been more readily associated with non-monological collectivity; as Deleuze's argues in his essay on Melville's Bartleby, the archipelago offers a model of "a world in process" rather than reified stasis; it is 'freedom' (Deleuze, 1997: 86).

\section{A String of Archipelagos}

The Phoenician network of trade routes built around merchant cities, the Minoan civilization, the rule of the Republic of Venice in the Middle Ages, the dominance of the Repubbliche Marinare (Pisa, Genoa, Venice, Amalfi): here are similar assemblages (Horden \& Purcell, 2000: 134). All such instantiations are of an "extended archipelago [in the Mediterranean] ... the most hospitable sea on the globe" (Braudel, 1972: 115). Think, too, of the Haida Gwaii Nation and the Tlingit Confederation in British Columbia, Canada (Tollefson, 2003). Consider that the British empire relied on strategic island or peninsular fortresses at Aden, Hong Kong, Malta, Singapore, or Gibraltar (Lambert, 2005); or that Japanese imperial ambitions during the Second World War were enacted across chains of islands; or that most of the so-called SIDS (small island developing states) are multi-island polities; or that if one conceives of the archipelago in obvious or simple terms, there are four large archipelagic countries each with populations well over 60 million: Indonesia, Japan, the Philippines and the United Kingdom.

However, if one seeks to complicate these simple or obvious categorizations, various possibilities emerge. Canada, for example, may not come readily to mind as an archipelago; and yet the prospect of white Arctic icescapes melting to islandscapes of brown, green and blue invites a range of imaginative articulations by which to consider the implications of fluid marine and terrestrial environments. Canada has the world's longest shoreline, straddles three oceans, contains the world's most extensive lake region, and is the country with the largest number of islands. Indeed, islands delineate all Canada's four extreme compass points: to the north, south, east and west. Thus, it is timely to consider Canada not as a unitary land mass but as a series of multiple assemblages of coastal, oceanic and insular identities, even as its centre of politico-economic gravity remains stuck in the Alberta tar sands (Vannini et al., 2009).

Such counter-mapping is also pertinent to the world's largest island and world's smallest continent of Australia (McMahon, 2003; 2010; Perera, 2009; Stratford et al., 2011). 'Australia' is a political fiction that has been projected differently over numerous historical epochs, lurching from island, to continent, to empire, to nation-but rarely to archipelago, and this despite the reckoning by Geoscience Australia (2009) that 8,222 islands, islets and rocky outcrops constitute this national space. There is also the somewhat different reckoning by the Australian Government Department of Immigration and Citizenship, which has excised islands such as Cocos, Christmas and Ashmore from the national space for the purpose of 'managing' asylum-seekers. This situation invites a return to:

... repeating island stories [that] highlight how island constructions traveled with European migration and voyaging. While St. Ursula's islands and Antillia became cartographically fixed by Columbus in the Caribbean, other imagined islands like the Antipodes (Terra Australis Incognita) moved westward, out of the Atlantic region into the Pacific (DeLoughrey, 2007: 12). 
The 'pursuit' of Australia in the geographical imagination - as it gained multiple expression in natural science, the humanities and emergent social sciences-was almost 'nesomaniacal' according to DeLoughrey, and hundreds of:

... explorers ... were sent to the Pacific to obtain this illusory counter-island to the northern hemisphere. Of course, these imagined island topographies were never homogeneously defined. Within their own time period they represented a system of ante-islands; heterotopias (ibid.).

Biogeography is equally rich in examples of assemblages in action. Archipelagoes are understood as constituted of multiple, isolated yet articulated habitats, shared eco-systems which can act as the locales for the unfolding of allopatric speciation and adaptive radiation (Losos \& Ricklefs, 2009). Here, consider Darwin's (1859/1979) studies of finches in the Galápagos, Wallace's (1880/1975) remarks of butterflies from the Aru Islands and, more recently, Kaneshiro and colleagues' (2005) drosophila (housefly) studies in Hawai'i.

\section{Immanent Constellations}

Returning to Benítez-Rojo and the possibilities that adhere to Chaos and the archipelago, it is useful to note that this is a unique assemblage (De Landa, 2006; Deleuze \& Guattari, 1986) and a complex ecology (Botkin, 1989; Haila \& Dyke, 2006), whereby "bits and pieces achieve significance in relation to others" (Law \& Mol, 1995: 276). The significance of the assemblage is ontogenic: it is not simply a gathering, a collection, a composition of things that are believed to fit together. Assemblages act in concert: they actively map out, select, piece together, and allow for the conception and conduct of individual units as members of a group. Deleuze \& Guattari (1986) use the example of constellations: assemblages of heavenly bodies that, like Orion the Hunter, take on one (or more) recognizable forms only when their wholeness arises out of a process of articulating multiple elements by establishing connections amongst them. An archipelago is similar: its framing as 'such and such an assemblage' draws our attention to the ways in which "practices, representations, experiences, and affects articulate to take a particular dynamic form" (Slack \& Wise, 2005: 129). Perhaps, at least as conceptual manifestations, archipelagos are fluid cultural processes, sites of abstract and material relations of movement and rest, dependent on changing conditions of articulation or connection.

DeLoughrey (2001: 23) is an early proponent of the need for such liquid narratives: in her case, in relation to island migrations that speak to the 'rosaries' of archipelagos that are the Pacific and Caribbean:

... no island is an isolated isle and ... a system of archipelagraphy - that is, a historiography that considers chains of islands in fluctuating relationship to their surrounding seas, islands and continents - provides a more appropriate metaphor for reading island cultures. Not surprisingly, writers from the Caribbean and Pacific such as Edouard Glissant, Epeli Hau'ofa, and Derek Walcott have called for a cartography of archipelagoes that maps the complex ebb and flow of immigration, arrival, and of island settlement. 
Assuredly, an archipelagic turn is salient in the Pacific: the first ocean to be settled, the last major island region to be colonized by the West, and the one that has proportionately witnessed most indigenous people survive 'the fatal impact' (Moorehead, 1990). The Pacific was probably the site of the development of the world's first ocean-going vessels and navigation systems, and the original settling of and travel between the islands, from which emerged powerful collective identities, as well as shared myths and languages (Nunn, 2009).

One of the best known, and most critiqued, expressions of this stance was offered by Epeli Hau'ofa (1993: 5) via exhortations to Polynesians to see themselves as a proud and powerful community that straddles across ocean and multiple jurisdictions as a sea of islands: "There is a gulf of difference between viewing the Pacific as 'islands in a far sea' and 'a sea of islands"'. Dening (1980), Ihimaera (2003) and Wendt (1977) complement this approach, deploying autochthonous Polynesian epistemologies in their work. Richards (2008) too, provides an alternative understanding of Polynesian settlement of the Pacific. Rather than consider a dispersal via canoe from a fixed 'homeland', he positions the Polynesian homeland, Hawaiki, as a space of 'mytho-praxis' connected through time and by voyaging, to the journeys of ancestors. In this way, Hawaiki's location shifted whenever the large double canoes ventured east, a new Hawaiki located, and itself becoming springboard for further migrations.

Consider, too, the name 'Tuvalu', which is inherently archipelagic. Its origins are uncertain, but it seems probable that the word 'Tuvalu' gained significance only after contact with nonOceanic peoples. Tu means 'to stand' and valu means 'eight'. The name Tuvalu draws on an identity based on shared senses of competition and cooperation between and among the communities of eight of nine islands in the archipelago - all except one being traditionally inhabited. The word may have found its initial spark of existence at the insistence of Donald Kennedy, an administrator, teacher and amateur anthropologist from New Zealand who lived in Tuvalu, then called the Ellice Islands, between two world wars. A possibly pivotal event is recounted (Paalo, 1981): when Kennedy insisted that a group of boys assisting him to conduct fieldwork should sit together and discuss a meaningful indigenous name for the Ellice Islands. 'Tuvalu' is what they agreed on. The name Atu Tuvalu — cluster of eight—was considered 'native' only a few decades later (Roberts, 1958). However, that the word Tuvalu is a recent creation is in dispute. Some record the name for Tuvalu before European contact as Te Atu Tuvalu - archipelago of eight, or eight standing together-suggesting a long-standing collective identity (Connell, 1980). Either way, it is a word that reflects the importance of the eight fenua that comprise this archipelagic state: a term denoting an island, its communities, and how community life is enacted in place and made mobile across places (also Farbotko, 2010a, 2010b). Whatever the origins of the word Tuvalu, it was legally and popularly recognized and cemented with the declaration of independence from Britain: October 1, 1978.

In the Caribbean, too, much has been done to delineate collective identity, shared sense of diaspora and history, settlement, mobility and change (Baldacchino, 2010; Connell, 1993; DeLoughrey, 2004; Lowenthal, 2007; McElroy, 2003; Sheller, 2009). Such labours underscore the archipelago's cultural relevance. This island region is much better marketed and branded in its totality than in its peculiarity; its most important exports - including various types of music and, of course, tourism - are likely more suggestive of the region than of its colonially fragmented political spaces. 


\section{A Wider Horizon: Returning To How}

In this emergent venture that invites from others a range of 'return conversations', we have sought to add to the revanchist stream of island studies research in two ways. First, we have highlighted particular limitations that arise from tenacious considerations of relations of land and sea, island and continent/mainland. We have posited that largely missing from these labours have been ontologies that illuminate island spaces as mutually constituted, coconstructed and inter-related. Second, we have mapped out and sought to justify a research agenda for a fuller exploration of a somewhat neglected, third set of relations: those pertaining to island and island.

We are drawn to such spaces of reflection because of the need for research on archipelagic relations as an antidote to the rhetorics of simpling, and in order to address the limitations and biases of dominant relations of land and sea, island and continent/mainland. Hence, the proposition that island studies scholars, and colleagues in allied fields, embrace agendas to explore alternative cultural geographies and alternative performances, representations and experiences of islands. Moreover, in the longer term we seek to understand how those who inhabit the archipelago, or how those who contemplate its spatialities, view, represent, talk and write about, or otherwise experience disjuncture, connection and entanglement between and among islands. In doing so, there is need to avoid presumptions about how archipelagic relations manifest, operate or circulate, for what would then remain to study?

Rather than advancing case studies, many island scholars are also keen to progress essentially comparative interdisciplinary work. Hence, this appeal for a (re)territorialization (Deleuze \& Guattari, 1986); a re-/mapping of island-island connectivities. All unique in their various Euclidian and metaphysical parameters, yet strangely similar in their islandness, islands qua archipelagos invite us to recover a history and a practice of what Brathwaite called tidalectics; of tossings, across and between seas, of people, things, processes and affects: "technologies for un-islanding" (Pugliese, 2011: 148). 'Middle Passages' become cognitive spaces in their own right, redolent with meaning; points and platforms of observation and not just spaces of flows. In unsettling the imperial binaries of land and water, island and continent/mainland, we seek relational paradigms that transcend, and do not merely overturn or reproduce, current classifications and conceptualizations. This search is motivated by a realization:

Every constituent of an archipelago is an island that can seem isolated in and by itself, and that it is only in analysing how currents move between and among them, by locating vantage points that give one a wider horizon, that the pattern that suggests an archipelago reveals itself (Sengupta, n.d.: 1).

In musing about a research agenda for archipelagos, hard questions of method arise. In acknowledging both 'island matters' and that 'islands matter', how might one unsettle, reorder and reposition the multiplicity of islands? How to conceive of these multiplicities as elemental in the production of knowledge? How to inscribe these in/to regimes of practice that often misalign with, jar or upset hegemonic narratives that appear locked in unequal, mainlandisland dichotomies or that view land-sea relations as necessarily truncating and obstructing? And, in lieu of such narratives, how to trace different, emergent and immanent articulations of being and of lived experiences? How do islanders perform their identity in terms of islandisland relations rather than, and apart from, island-mainland interactions? How do they 
represent islands in such terms? How do they see and re/present themselves, articulating their particularity in ways that may differ from those conceived from/by the centre? And can such ways of re/presentation be patterned, on the basis of what is shared across different islands?

We suspect that a focus on archipelagic text, talk and practice will embrace diverse methodological perspectives; given our proclivities, that includes the literary, artistic, geographical, cultural, anthropological and sociological. There is need, again, to be transparent about a basic premise here-theoretical and empirical archipelagic relations exist-and equally clear of a need to avoid assuming a priori how they may manifest. We also sense that a focus on text, talk and practice will allow scholars to occupy conceptual and empirical spaces between figure and ground - representational, performative and real spaces - in rethinking island-island, island/island, island:island relations (after Olsson, 1992), and the archipelago.

\section{Closing}

For island scholars beyond the natural sciences, the archipelago is a conceptual tool too little drawn upon. Yet, it could be so useful to break out of stultifying and hackneyed binaries; privileging instead the power of cross-currents and connections, of complex assemblages of humans and other living things, technologies, artefacts and the physical scapes they inhabit.

Is it possible to listen and attend to this prospect for critical practice if we are theoretically tone-deaf to its tonality and timbre? The possibility of an absence of the necessary cognitive apparatus recalls Lyotard's formulation of the differend - of incommensurability and noncomprehension across cultures, beliefs and perspectives. Fittingly, Lyotard imagines one salve to this impasse as a movement between the islands of an archipelago; indeed, the movement creates the relation of an archipelago. He suggests that the translator, the one moving between the absolute difference and particularity of each island, can have no object of her own, no island home, only a milieu or field, which is the sea, the "archepelagos, or primary sea, as the Aegean was once called" (Lyotard, 1996: 131), liquid and exploratory narratives, performative geographies. This sea, of course, is another cultural space, but Lyotard's archepelagos resounds here with Hau'ofa's sea of islands. As a critical model, it advocates the necessary non-fixity of the researcher of islands who is perennially off home ground; at sea.

\section{Acknowledgements}

The ideas behind this paper have benefited from discussions held amongst the five of us at the University of Tasmania, Hobart, Australia, on 25 March 2011, and continued thereafter. An earlier draft of this paper was presented at the $2^{\text {nd }}$ international 'island dynamics' conference held in Floriana, Malta, in May 2011. We note and have welcomed rigorous and helpful comments provided by referees in the review stage: the usual disclaimers apply.

\section{References}

Baldacchino, G. (2002) 'Jurisdictional Self-Reliance for Small Island Territories: Considering the Partition of Cyprus', Round Table, Vol. 365, No. 1, pp. 349-360.

Baldacchino, G., ed. (2007) A World of Islands: An Island Studies Reader, Charlottetown, Canada, Institute of Island Studies, University of Prince Edward Island. 
Baldacchino, G. (2008) 'Studying Islands: On Whose Terms? Some Epistemological and Methodological Challenges to the Pursuit of Island Studies', Island Studies Journal, Vol. 3, No. 1, pp. 37-56.

Baldacchino, G. (2010) 'Islands and Beers: Toasting a Discriminatory Approach to Small Island Manufacturing', Asia Pacific Viewpoint, Vol. 51, No. 1, pp. 61-72.

Barter, P. (2007) 'Central Singapore Island; Peripheral Mainland Johor: Making the Link' in G. Baldacchino (ed.) Bridging Islands: The Impact of Fixed Links, Charlottetown, Canada, Acorn Press, pp. 261-276.

Beer, G. (1989) 'Discourses on the Island' in F. Amrine (ed.) Literature and Science as Modes of Expression, Boston MA, Kluwer Academic Publishers, pp. 1-27.

Benítez-Rojo, A. (1996) The Repeating Island: The Caribbean and the Postmodern Perspective, Durham NC, Duke University Press.

Berry, R.J. (2009) Islands, London, Collins.

Botkin, D. (1989) Discordant Harmonies: A New Ecology for the Twenty-First Century, Oxford, Oxford University Press.

Bourke, R. (2010) 'Pocock and the Presuppositions of the New British History', The Historical Journal, Vol. 53, No. 3, pp. 747-770.

Brathwaite, E.K. (1983) 'Caribbean Culture: Two Paradigms' in J. Martini (ed.) Missile and Capsule, Bremen, Germany, Universitat Bremen, pp. 9-54.

Brathwaite, E.K. (1988) The Arrivants: A New World Trilogy--Rights of Passage / Islands / Masks, London and New York, Oxford University Press.

Braudel, F. (1972) The Mediterranean and the Mediterranean World in the Age of Philip Ii, Vol. I, Translated by Siân Reynolds, London, Collins.

Connell, J. (1980) 'Atu Tuvalu: Group of Eight', Hemisphere, Vol. 25, No.1, pp. 102-107.

Connell, J. (1993) 'Anguilla: The Tourist Trajectory in a Microstate', Caribbean Geography, Vol. 4, No. 2, pp. 131-138.

Conrad, P. (2009) Islands: A Trip through Time and Space, London, Thames and Hudson.

Constantakopoulou, C. (2007) The Dance of the Islands: Insularity, Networks, the Athenian Empire, and the Aegean World, Oxford, Oxford University Press.

Darwin, C. (1859/1979) On the Origins of Species by Means of Natural Selection, or the Preservation of Favoured Races in the Struggle for Life, New York, Avenel Books. 
De Landa, M. (2006) A New Philosophy of Society: Assemblage Theory and Social Complexity, London, Continuum.

Deleuze, G. (1997) 'Bartleby; or, the Formula' in Essays Critical and Clinical, Minneapolis MN, University of Minnesota Press, pp. 68-90.

Deleuze, G. (2004) Desert Islands and Other Texts 1953-1974, Los Angeles CA, Semiotext(e).

Deleuze, G. \& Guattari, F. (1986) Kafka: Towards a Minor Literature, Minneapolis MN, University of Minnesota Press.

DeLoughrey, E. (2001) "'The Litany of Islands, the Rosary of Archipelagoes": Caribbean \& Pacific Archipelagraphy', Ariel: Review of International English Literature, Vol. 32, No. 1, pp. 21-51.

DeLoughrey, E. (2004) 'Island Ecologies and Caribbean Literatures', Tijdschrift voor Economische en Sociale Geografie, Vol. 95, No. 3, pp. 298-310.

DeLoughrey, E. (2007) Routes and Roots: Navigating Caribbean and Pacific Island Literatures, Honolulu HI, University of Hawai'i Press.

Dening, G. (1980) Islands and Beaches. Discourse on a Silent Land, Marquesas: 1774-1880, Honolulu HI, University of Hawai'i Press.

Dening, G. (2004) Beach Crossings: Voyaging across Times, Cultures, and Self, Philadelphia PA, University of Pennsylvania Press.

Edmond, R. \& Smith, V. (eds.) (2003) Islands in History \& Representation, New York, Routledge.

Farbotko, C. (2010a) 'The global warming clock is ticking so see these places while you can: Voyeuristic tourism and model environmental citizens on Tuvalu's disappearing islands', Singapore Journal of Tropical Geography, Vol. 31, No. 2, pp. 224-238.

Farbotko, C. (2010b) 'Wishful sinking: disappearing islands, climate refugees and cosmopolitan experimentation', Asia Pacific Viewpoint, Vol. 51, No. 1, pp. 47-60.

Farbotko, C. (2008) Representing Climate Change Space: Islographs of Tuvalu, PhD Dissertation, Hobart, University of Tasmania, School of Geography \& Environmental Studies.

Fletcher, L. (2011) '... Some Distance to Go': A Critical Survey of Island Studies, New Literatures Review. Vols. 47-48, pp. 17-34.

Geoscience Australia (2009) 'Education - Geoscience Basics - Islands', www.ga.gov.au/education/geoscience-basics/landforms/islands.jsp. 
Gibson-Graham, J.K. (1998) Islands: Culture, Economy, Environment. Second Joint Conference of the Institute of Australian Geographers and New Zealand Geographical Society, January 28-31, Hobart, New Zealand Geographical Society Conference Series No.19.

Gillis, J.R. (2004) Islands of the Mind: How the Human Imagination Created the Atlantic World, New York, Palgrave Macmillan.

Glissant, E. (1997) Poetics of Relation. Trans. Betsy Wing, Ann Arbor MI, University of Michigan Press.

Glissant, E. (2005) Collected Poems of Edouard Glissant, translated by J. Humphreys, Minneapolis MN, University of Minnesota Press.

Haila, Y. \& Dyke, C. (eds.) (2006) How Nature Speaks: The Dynamics of the Human Ecological Condition, Durham NC, Duke University Press.

Harwood, A. (2011) The Political Constitution of Islandness: The 'Tasmanian Problem' and Ten Days on the Island, PhD Dissertation, Hobart, University of Tasmania, School of Geography \& Environmental Studies.

Hau'ofa, E. (1993) 'Our Sea of Islands' in E. Waddell, V. Naidu \& E. Hau'ofa (eds.) A New Oceania: Rediscovering Our Sea of Islands, Suva, Fiji, University of the South Pacific, pp. 2-16.

Ihimaera, W. (2003) The Whale Rider, New Zealand, Graphia.

Kaneshiro, K.Y., Chinn, P., Duin, K.N., Hood, A.P., Maly, K. \& Wilcox, B. (2005) 'Hawaii's Mountain-to-Sea Ecosystems: Social-Ecological Microcosms for Sustainability Science and Practice', EcoHealth, Vol. 2, No. 1, pp. 1-12.

King, R. (1993) 'The Geographical Fascination of Islands' in D. Lockhart, D. Drakakis-Smith \& J. Schembri (eds.) The Development Process in Small Island States, London, Routledge, pp.13-37.

Lambert, D. (2005) "As Solid as the Rock'? Place, Belonging and the Local Appropriation of Imperial Discourse in Gibraltar', Transactions of the Institute of British Geographers NS, Vol. 30, No. 2, pp. 206-220.

Law, J. \& Mol, A. (1995) 'Notes on Materiality and Sociality', The Sociological Review, Vol. 43, No. 2, pp. 274-294.

Lewis, M.W. \& Wigen, K.E. (1997) The Myth of Continents: A Critique of Metageography, Berkeley CA, University of California Press.

Losos, J.B. \& Ricklefs, R.E. (2009) 'Adaptation and Diversification on Islands', Nature, Vol. 457, No. 7231, pp. 830-836. 
Lowenthal, D. (2007) 'Islands, Lovers and Others', Geographical Review, Vol. 97, No. 2, pp. 202-229.

Lyotard, J.F. (1996) The Differend: Phrases in Dispute, Minneapolis MN, University of Minnesota Press.

Maddern, J.F. \& Adey, P. (2008) 'Editorial: Spectro-Geographies', Cultural Geographies, Vol. 15, No. 3, pp. 291-295.

McElroy, J.L. (2003) 'Tourism Development in Small Islands across the World', Geografiska Annaler, Vol. 85B, No. 4, pp. 231-242.

McMahon, E. (2003) 'The Gilded Cage: From Utopia to Monad in Australia's Island Imaginary' in R. Edmond \& V. Smith (eds.) Islands in History and Representation, London, Routledge, pp. 190-202.

McMahon, E. (2010) 'Australia, the Island Continent: How Contradictory Geography Shapes the National Imaginary', Space and Culture, Vol. 13, No. 2, pp. 178-187.

Merivale, C. (1865) History of the Romans under the Empire, London, Longmans, Green \& Co.

Moorehead, A. (1990) The Fatal Impact: The Invasion of the South Pacific: 1767-1840, New York, Harper Collins.

Nunn, P. (2009) Vanished Islands and Hidden Continents of the Pacific, Honolulu HI, University of Hawai'i Press.

Olsson, G. (1992) 'Lines of Power' in T. Barnes \& J. Duncan (eds.) Writing Worlds: Discourse, Text \& Metaphor in the Representation of Landscape, London, Routledge, pp. 86-96.

Paalo, P.F. (1981) Tuvalu Mo Te Atua: An Attempt at Interpretation, Bachelor of Divinity Thesis, Suva, Fiji Islands, Pacific Theological College.

Perera, S. (2009) Australia and the Insular Imagination: Beaches, Borders, Boats and Bodies, New York, Palgrave Macmillan.

Pocock, C. (2005) "Blue Lagoons and Coconut Palms': The Creation of a Tropical Idyll in Australia', Australian Journal of Anthropology, Vol. 16, No. 3, pp. 335-349.

Pugliese, J. (2011) 'Review of S. Perera: Australia and the Insular Imagination: Beaches, Borders, Boats and Bodies', Continuum, Vol. 25, No. 1, pp. 134-137.

Richards, C. (2008) 'The Substance of Polynesian Voyaging', World Archaeology, Vol. 40, No. 2, pp. 206-223. 
Roberts, R.G. (1958) 'Te Atu Tuvalu: A Short History of the Ellice Islands', Journal of the Polynesian Society. Vol. 67, pp. 394-423.

Said, E.W. (1978) Orientalism, New York, Vintage Books.

Seigworth, G.J. \& Gregg, M. (2010) 'An Inventory of Shimmers' in G.J. Seigworth \& M. Gregg (eds.) The Affect Theory Reader, Durham NC, Duke University Press, pp. 1-25.

Sengupta, S. (n.d.) 'Notes for Keynote Conversation', www2.asialink.unimelb.edu.au/arts/projects/forum2004/ssengupta.pdf

Sheller, M. (2009) 'Infrastructures of the Imagined Island: Software, Mobilities and the Architecture of Caribbean Paradise', Environment \& Planning A, Vol. 41, No. 6, pp. 1386-1403.

Slack, J.D. \& Wise, J.M. (2005) Culture + Technology: A Primer, New York, Peter Lang.

Stratford, E. (2006) 'Technologies of Agency and Performance: Tasmania Together and the Constitution of Harmonious Island Identity', Geoforum, Vol. 37, No. 2, pp. 273-286.

Stratford, E. (2008) 'Islandness and Struggles over Development: A Tasmanian Case Study', Political Geography, Vol. 27, No. 2, pp. 160-175.

Stratford, E., McMahon, E., Farbotko, C., Jackson, M. \& Perera, S. (2011) 'Review Forum: S. Perera's 'Australia \& the Insular Imagination'", Political Geography, Vol. 30, No. 6, pp. 329-338.

Tollefson, C. (2003) 'Indigenous Rights and Forest Certification in British Columbia' in J. Kirton \& V. MacLaren (eds.) Hard Choices and Soft Law: Trade, Environment and Social Cohesion in Global Governance, Aldershot, Ashgate, pp. 93-120.

Vannini, P., Baldacchino, G., Guay, L., Royle, S.A. \& Steinberg, P.E. (2009) 'Recontinentalizing Canada: Arctic Ice's Liquid Modernity and the Imagining of a Canadian Archipelago', Island Studies Journal, Vol. 4, No. 2, pp. 121-138.

Walcott, D. (1991) Omeros, Boston MA, Faber and Faber.

Walcott, D. (1992) 'Nobel Prize $\quad$ Speech', www.nobelprize.org/nobel_prizes/literature/laureates/1992/walcott-lecture.html.

Wallace, A.R. (1880/1975) Island Life, or the Phenomena and Causes of Insular Faunas and Floras, Including a Revision and Attempted Solution to the Problem of Geological Climates, New York, AMS Press.

Wendt, A. (1977) Pouliuli, Honolulu HI, University of Hawai’i Press.

Williams, S. (2010) 'On Islands, Insularity, and Opium Poppies: Australia's Secret Pharmacy', Environment and Planning D: Society and Space, Vol. 28, No. 2, pp. 290-310. 